\title{
0 futebol-arte brasileiro: uma tradição continuamente reinventada e contestada
}

\author{
Brazilian Art-Football: \\ A Tradition Continuously Reinvented and Contested
}

José Carlos Marques

Universidade Estadual Paulista Júlio de Mesquita Filho, Bauru/Brasil Doutorado em Ciências da Comunicação, Universidade de São Paulo zeca.marques@uol.com.br

Nathaly Barbieri Marcondes César Mestrado em Comunicação, Universidade Estadual Paulista Júlio de Mesquita Filho

\begin{abstract}
Resumo: 0 futebol brasileiro, desde a primeira metade do Século XX, tem sido comumente associado a uma prática em que predominariam as noções de magia, habilidade, fantasia e espetáculo, muito em função da valorização das individualidades e da capacidade de driblar de nossos atletas. Se, por um lado, há uma legitimação - especialmente pelo discurso midiático - de que o futebol brasileiro é caracterizado por meio do futebol-arte, alguns estudos acadêmicos das últimas duas décadas no Brasil, por outro lado, problematizam ou recusam essa caracterização quando se observa o futebol nacional, especialmente o praticado pela Seleção Brasileira. Assim, este artigo procura verificar como a visão fundada por Gilberto Freyre (1938) a respeito do futebol-arte ainda mantém força, renovada a cada Copa do Mundo especialmente por emissoras televisivas, ao passo que outros discursos procuram desmistificar tal visão.
\end{abstract}

Palavras-Chave: Futebol brasileiro; Copa do Mundo; Discurso; Mídia.

ABSTRACT: Brazilian football, since the first half of the 20th century, has been commonly associated with a practice in which the notions of magic, skill, fantasy and spectacle, predominate, much in function of the valorization of individualities and the ability to dribble of our athletes. If, on the one hand, there is legitimacy especially in the media discourse - that Brazilian football is characterized by "art football", some academic studies of the last two decades in Brazil, on the other hand, problematize or refuse this characterization when national football is observed, especially the one practiced by the Brazilian Selection. Thus, this article seeks to verify how the vision founded by Gilberto Freyre (1938) on "art football" still maintains strength, renewed every World Cup especially by television broadcasters, while other discourses seek to demystify this vision.

KEYwordS: Brazilian Football; World Cup; Speech; Media. 


\section{INTRODUÇÃo}

O futebol brasileiro, desde a primeira metade do Século XX, tem sido comumente associado a uma prática em que predominariam as noções de magia, habilidade, fantasia, espetáculo etc., muito em função da valorização das individualidades e da capacidade de driblar de nossos atletas. Em diferentes produtos midiáticos, não é raro depararmo-nos com algum tipo de alusão ao chamado futebol-arte, prerrogativa quase que exclusiva dos atletas nascidos em solo pátrio. Por outro lado, estudos realizados especialmente nas últimas duas décadas na academia brasileira começaram a colocar em xeque a aplicação uníssona do conceito do futebol-arte ao futebol brasileiro, demonstrando que essa associação tem sido construída e posta em marcha também pelos meios de comunicação.

Sobre o futebol-arte brasileiro, sabe-se que um dos primeiros a utilizar tal expressão foi o sociólogo Gilberto Freyre (1938; 1947). Divergindo dos discursos dominantes de sua época, Freyre acreditava na supremacia do mulato brasileiro, alegando que essa parcela da população concentraria as melhores qualidades das "raças" negra e branca. Com o início da popularização do futebol e a crescente entrada de jogadores negros de comprovada habilidade em clubes brasileiros, o autor alega que os afrodescendentes brasileiros emprestaram suas melhores qualidades para que a forma de se praticar futebol no Brasil se diferenciasse de outras no mundo. Ele cita influências vindas de práticas como o samba, as religiões com raízes africanas e, especialmente, a capoeira, dizendo que esta mistura de elementos deu ao futebol brasileiro uma plasticidade única, a ponto de ele poder ser comparado a uma arte.

São vários os autores que também procuraram valorizar as qualidades artísticas do futebol brasileiro e sua capacidade de adquirir aspectos de outras culturas. $O$ crítico literário alemão Anatol Rosenfeld (1993), por exemplo, dedicou alguns de seus textos à análise do futebol brasileiro e às influências recebidas da cultura africana. Outros pesquisadores, como o antropólogo Roberto DaMatta (1982; 1994) e o crítico literário José Miguel Wisnik (2008), também propuseram algumas chaves para se compreender o futebol brasileiro, buscando verificar as 
singularidades e particularidades da prática desse esporte em nosso país. 0 cineasta italiano Pier Paolo Pasolini (2005), por sua vez, faz uma análise muito similar à de Freyre, classificando o futebol brasileiro como um futebol de "poesia" em contraposição ao futebol de "prosa" executado pelas seleções europeias.

No entanto, em meio a este discurso tão difundido e aparentemente bem aceito pela sociedade de que o futebol brasileiro seria sinônimo de futebol-arte, surgem alguns pesquisadores que colocam este juízo em questão. Citando a publicação de Freyre como fundador desta ideia sobre o futebol brasileiro, Simoni Lahud Guedes (2014) acredita que são apenas momentos pontuais, como algumas jogadas singulares, que justificam a fala sobre o talento dos jogadores brasileiros. Assim, a longa exposição desses exemplos pela mídia só acabaria fortalecendo esse discurso. Outros autores como Ronaldo Helal, Hugo Lovisolo, Antônio Jorge Soares e Hilário Franco Júnior $(2002 ; 2003 ; 2004 ; 2012 ; 2013)$ também colocarão em outra perspectiva o futebol-arte freyreano, alegando que se trata de uma exceção mais do que de uma regra com relação à pratica desse esporte no país. Uma das hipóteses levantada por estes autores é a tentativa de a mídia brasileira enaltecer o talento inato dos jogadores que disputaram a Copa do Mundo de 1970, em uma seleção que passou por intenso treinamento e capacitação física, utilizando-se de conhecimentos científicos avançados para a época no que diz respeito à preparação para as altas temperaturas e a altitude do México, onde se realizou aquela competição.

O pesquisador Tiago Maranhão (2006), também comentando a obra de Freyre, irá sugerir que a visão do autor sobre o futebol brasileiro conseguiu sua consolidação pelo fato de ter sido difundida pelo Presidente Getúlio Vargas durante o Estado Novo (1937-1945) como forma de provocar a unidade nacional e o sentimento de nacionalismo em uma população que até então se identificava mais com os países do Hemisfério Norte (no caso dos imigrantes) ou com as potências hegemônicas de então. Não somente Vargas, mas também outros líderes políticos se apropriaram da popularidade do futebol para efetuar algum tipo de controle sobre a sociedade, utilizando o esporte como forma de manipulação para unificar a população em um objetivo comum: torcer pela seleção brasileira em competições mundiais. 
Tudo isto, somado à divulgação em massa feita pela mídia da ideia do futebol-arte, fez com que este discurso tivesse se tornado dominante na sociedade brasileira, sendo difundido inclusive em outras partes do mundo, embora existam ensaios recentes que provem o contrário. Pensando nisto, este artigo trabalha com a oposição de dois discursos a respeito do futebol brasileiro que se mostram contrários e difusos. Um deles tem como precursor Gilberto Freyre, que alega haver certa plasticidade do futebol brasileiro, comparando-o a uma arte e incluindo-o como patrimônio da nação. Tal conceito foi utilizado como elemento de construção da identidade nacional e é reavivado continuamente pelos meios de comunicação. 0 outro conceito, mais hodierno, surge na academia e aparece como forma de desmistificar o imaginário criado pela primeira linha de discurso, apresentando fatos que comprovam que o "mito" do futebol-arte freyreano é na verdade inverídico. Desta forma, nosso intuito neste artigo é contrapor o discurso sobre o futebol-arte ao discurso que se apoia nas prestações da Seleção Brasileira nas últimas Copas do Mundo, quando a ideia cristalizada de que praticaríamos um jogo habilidoso e de apuro técnico não se sustentaria tão facilmente.

\section{A CONSTRUÇÃO DA IDENTIDADE NACIONAL EM TORNO DO FUTEBOL}

Pode-se dizer que o futebol no Brasil se desenvolveu como uma "tradição inventada", segundo os conceitos de Eric Hobsbawn (1997). De acordo com o historiador britânico, este termo pode significar tanto as tradições realmente inventadas, mas construídas de forma institucionalizada, como aquelas que surgem em um período determinado do tempo e se estabelecem com rapidez. Hobsbawn descreve a tradição inventada como um "conjunto de práticas, normalmente reguladas por regras tácita ou abertamente aceitas; tais práticas, de natureza ritual ou simbólica, visam inculcar certos valores e normas de comportamento através da repetição, o que implica, automaticamente, uma continuidade em relação ao passado". ${ }^{1}$ Desta forma, percebe-se que a admiração do brasileiro pelo futebol trata-se de uma tradição inventada principalmente por

\footnotetext{
${ }^{1}$ HOBSBAWN. A invenção das tradições, p. 9.
} 
sua característica histórica e pela rapidez com que se tornou uma manifestação de identificação social.

Para Hobsbawn, a tradição se difere do costume por se tratar de algo invariável, ou seja, enquanto os costumes de um grupo social podem sofrer adaptações ao decorrer dos tempos, as tradições se mantêm fixas, de acordo com o passado a que se referem. Quando aplicados ao futebol no Brasil, estes termos poderiam ser explicados da seguinte forma: o costume seria a forma de o brasileiro incluir o futebol no seu cotidiano, que muda de acordo com as circunstâncias da sociedade, seja com as peladas na rua, com o acompanhamento dos jogos pela TV ou com qualquer outra forma de interagir com este esporte; já a tradição faria referência à forma como o futebol foi historicamente incutido na identidade do "ser brasileiro", assim como o samba e a figura do malandro. A invenção de certas tradições acontece, segundo Hobsbawn, quando uma tradição se torna "velha", ultrapassada demais para a realidade atual de uma sociedade. Neste caso, pode-se pensar que a tradição do futebol no Brasil surgiu quando a divisão social existente entre as elites e o restante da população começa a entrar em decadência, e o esporte se apresenta às camadas menos favorecidas como forma de ascensão social.

Para DaMatta (1994), no caso do Brasil, foi o futebol que possibilitou ao povo mais acesso aos símbolos nacionais, como a bandeira, o hino e as cores características do país, elementos antes pertencentes somente a uma elite. 0 autor ainda acredita que o futebol permite um maior senso de patriotismo, possibilitando amar a pátria independentemente do que a classe dominante prega sobre as potências americanas e europeias:

Foi, portanto, só com o futebol que conseguimos, no Brasil, somar Estado nacional e sociedade. E, assim fazendo, sentir, [...] a confiança na nossa capacidade como povo criativo e generoso. Povo que podia vencer como país moderno, que podia, também, finalmente, cantar com orgulho o seu hino, e perder-se emocionado dentro do campo verde da bandeira nacional. ${ }^{2}$

Vogel (1982) também descreve a importância do futebol na identidade nacional brasileira ao dizer que o torcedor possui um lugar de destaque na sociedade. Assim como nome, religião e outros costumes, o futebol é algo

\footnotetext{
${ }^{2}$ DAMATTA. Antropologia do óbvio, p. 17.
} 
praticamente herdado para os cidadãos brasileiros, já que logo no início de suas vidas são cobrados sobre a escolha do time pelo qual irão torcer. A dimensão que este esporte ocupa socialmente pode ser percebida quando se leva em conta o espaço destinado a ele nas interações sociais. Além de ser um dos temas preferidos das conversas entre amigos, por meio dele podem ser reveladas afinidades ou discordâncias: "Dos colunáveis aos frequentadores de botequim, o futebol tece uma intrincada rede de relações". ${ }^{3} 0$ autor conclui dizendo que este esporte teria aberto uma via de acesso para a compreensão da imaginação e da realidade social brasileira, já que a identidade nacional tem no futebol uma estratégia de manipulação e definição, contribuindo para a socialização dos brasileiros no que diz respeito à cultura e às noções de hierarquia e igualdade.

Maranhão (2006) comenta ainda o papel do futebol na construção da identidade nacional brasileira. Segundo ele, o futebol representa um aglutinador de emoções, especialmente no Brasil, o que faria parte do espírito de nacionalidade. Sempre durante competições internacionais é que se tornam claras as avaliações a respeito do desempenho da Seleção Brasileira de acordo com a ideia de que se tem do "ser brasileiro", quer o resultado seja positivo, quer seja negativo. Gastaldo (2002) também considera que a competição mundial de futebol representa, para os brasileiros, um momento de celebração muito mais verdadeiramente nacional do que o dia 7 de setembro, em que oficialmente se comemora a Independência do Brasil. A Copa do Mundo teria essa característica já que remete a um ideal de nacionalidade triunfante, ou seja, uma competição internacional em que o Brasil é reconhecido como um dos melhores participantes, mesmo quando não vence.

De acordo com o posicionamento dos autores citados anteriormente, é inegável o fato de que o futebol ocupa um espaço importante no cotidiano da população brasileira, tornando-se um dos elementos que caracteriza o "ser brasileiro". No entanto, muito da relação entre a identidade nacional com este esporte se deve ao fato de a política ter percebido a influência que ele começava a desempenhar sobre os hábitos sociais e ter-se utilizado dele como forma de criar

\footnotetext{
${ }^{3}$ VOGEL. O momento feliz - reflexões sobre o futebol e o ethos nacional, p. 78.
} 
uma unidade social. Para Vogel (1982) seria justamente por este motivo que alguns observam o esporte como "o ópio das massas populares", já que ele seria um elemento de fácil manipulação utilizado pelos poderosos para controlar os menos favorecidos, devido às paixões ligadas a ele.

No início dos anos 1920, o bom desempenho dos jogadores e a massificação do futebol brasileiro são incorporados nas narrativas a respeito de questões de nacionalidade (Soares; Lovisolo, 2003). Ainda em 1921, no período em que o futebol ainda sofria interferências do extremo racismo da sociedade, quando a seleção brasileira se preparava para disputar o Campeonato Sul-Americano em Buenos Aires, o então Presidente da República Epitácio Pessoa teria recomendado aos dirigentes que levassem apenas jogadores brancos, excluindo os atletas negros e mulatos. Como justificativa, ele dizia que o Brasil deveria ser representado no cenário internacional por sua "melhor sociedade". Apesar do teor preconceituoso dos motivos relatados pelo Presidente, cabe notar que já se percebia, pela política, o futebol como uma forma de projetar a imagem nacional no exterior (Máximo, 1999). No entanto, Epitácio Pessoa não foi o primeiro a perceber o potencial de representação diplomática do futebol, e nem seria o último.

Já nos anos de 1930, o futebol legitima-se como expressão da nacionalidade, por meio de narrativas como as citadas anteriormente, de autores como Mário Filho e Gilberto Freyre, e do maior espaço dedicado a ele na imprensa. Então Presidente da República neste período, Getúlio Vargas tem como um dos principais objetivos durante seu governo superar a falta do sentimento de pertença nacional dos brasileiros, em decorrência do alto número de imigrantes que chegaram ao país.

O fato é que a Copa de 1938 permitiu que se percebesse a unidade causada pelo futebol, ao tornar-se um elemento comum a pessoas originadas de diferentes localidades e esferas sociais. Campanhas como a do "selo pró-seleção" incentivavam a população do país a auxiliar o scratch, dizendo ser este um dever de todo brasileiro (Franzini, 2000). Além da nacionalização do próprio esporte, o sentimento causado pela participação da seleção brasileira na competição começava a transformar o futebol em um dos maiores símbolos da brasilidade.

Concretizava-se então a ligação entre o nacionalismo do Estado e o sentimento da população, com constantes referências a Getúlio e aos interesses do 
país. Com a empolgação provocada pela participação da seleção brasileira no Mundial de 1938 e a comoção com o terceiro lugar para uma equipe que, segundo muitos, merecia o primeiro, Vargas utiliza a unidade causada pelo futebol para criar certa identificação nacional na sociedade, colocando até mesmo alto-falantes nas ruas para que todos os cidadãos fossem capazes de acompanhar as partidas. Maranhão atenta ainda ao fato de que a intensa divulgação da Copa de 1938 promovida por Getúlio Vargas para criar certa identificação nacional com a seleção colaborou para que a visão de Freyre sobre o futebol brasileiro fosse difundida de forma mais alargada.

\section{O FUTEBOL-ARTE OU O DISCURSO EUFÓRICO SOBRE O FUTEBOL BRASILEIRO}

Desde o início do século XX, quando negros, mulatos e pessoas de classes sociais mais baixas começaram a ter protagonismo no futebol brasileiro, estabeleceu-se uma nova reputação sobre este esporte no Brasil, principalmente quando ele é comparado ao estilo dos europeus. DaMatta (1982) acredita que o futebol brasileiro permitiria a expressão social por meio de uma perspectiva, de regras, relações, objetos, gestos e ideologias. A influência que o futebol recebe da sociedade brasileira seria explicada por esta visão do esporte como forma de expressão. Sendo uma atividade da sociedade, o futebol brasileiro carrega consigo os costumes e a cultura da sociedade que o acolheu.

Este olhar sobre o futebol brasileiro, celebrado por parte do meio acadêmico e pela maior parte dos meios de comunicação, tem a ver com a ideia de que o jogador pátrio, por força da incorporação de elementos da cultura africana, seria o responsável por colocar em prática o chamado futebol-arte, conceito que tem origem no sociólogo, antropólogo e escritor Gilberto Freyre, com o artigo "Foot-ball mulato", publicado no Diário de Pernambuco em 17 de junho de 1938. 0 texto causará enorme influência no imaginário nacional, inspirando sobremaneira o olhar que será dedicado desde então ao futebol pela imprensa esportiva brasileira e pelos fãs do esporte, de forma geral. Nesse texto, Freyre discorre sobre a atuação da seleção brasileira de futebol na Copa do Mundo da França, que ocorreu no mesmo ano da publicação do artigo. 0 autor chama a atenção para a 
coragem que o Brasil teve ao enviar à competição um time que, com exceção de alguns brancos, era composto por uma maioria de jogadores negros e mulatos. E é devido a esta composição, reflexo da própria sociedade brasileira, que Freyre diz ser o estilo de se jogar futebol no Brasil diferente do estilo europeu.

Elementos característicos presentes na sociedade brasileira, como a manha, a ligeireza, a astúcia e a espontaneidade individual são os principais diferenciais do futebol brasileiro. Freyre (1938) compara o jogo brasileiro com o jogo dos europeus, fazendo menção às classificações de dionisíaco e apolíneo, em referência aos deuses Apolo e Dionísio, figuras da mitologia grega. 0 estilo brasileiro, dionisíaco, não se limitaria ao método técnico, sendo caracterizado pelo floreio e pelo improviso, ganhando liberdade para ostentar talentos individuais. Já o estilo europeu, apolíneo, tentaria eliminar estes elementos em benefício da técnica científica. E nesta descrição entre ambos os estilos é que Freyre compara, pela primeira vez, o futebol brasileiro a uma arte.

Anatol Rosenfeld (1993), assim como Freyre, também relaciona o futebol brasileiro a traços de celebrações como as saturnálias romanas primitivas, em que eram suspensas as diferenças de nível social, ou à festa da primavera sumeriana, ligada à soberania múltipla de um rei saído do povo. Em relação à comparação de latinos e europeus a respeito de seus estilos de jogo, o cineasta italiano Pier Paolo Pasolini (2005) faz uma interessante contribuição comparando cada um desses estilos a duas formas literárias: a prosa e a poesia. Segundo Pasolini, a partir do momento em que um sistema de signos não precisa necessariamente ser formado por palavras, abrindo a possibilidade de um conjunto composto por gestos ou movimentos, o futebol pode, por sua vez, ser considerado um sistema de signos, já que possui todas as características fundamentais de linguagem.

Pasolini cria esta fundamentação embasada na comparação do futebol com a linguagem para demonstrar que, assim como a fala e a escrita, este esporte possui uma articulação, fazendo com que alguns atletas, ou mesmo seleções inteiras, sejam reconhecidos por um "discurso" prosaico, enquanto outras são tidas como poéticas. Sem pretender atribuir valor a uma ou outra forma, o autor classifica alguns momentos durante o jogo como essencialmente poéticos, como o gol ou os dribles, e, devido a isso, o futebol praticado pela seleção brasileira 
poderia se aproximar da forma "poética" a que ele se refere, já que ele a vê como um conjunto dos "melhores dribladores do mundo e os melhores fazedores de gol". Já em relação ao futebol prosaico, Pasolini descreve-o como um jogo baseado na coletividade e na organização, relacionando-o ao estilo europeu de praticar este esporte, com um jogo organizado coletivamente e executado segundo as regras do código. De certa forma, o futebol brasileiro seria mais admirado pela não busca do gol, ou seja, os elementos pelos quais ele é valorizado seriam "o esforço sem funcionalidade, o deleite e o desperdício, o prazer e o erotismo do drible como atividade lúdica, a transgressão do útil”. ${ }^{4}$

É interessante notar na obra de Freyre (1938) que, ao longo de seu texto, o autor procura destacar no futebol brasileiro a característica de se permitir um maior destaque à individualidade, o que poderia representar uma possível contradição, uma vez que se trata de um esporte praticado em coletividade. 0 autor afirma que a possibilidade de se enxergar a beleza individual no talento de cada jogador é um dos maiores trunfos do estilo brasileiro, ao mesmo tempo em que aponta o sistema mais colaborativo dos europeus como um defeito. 0 fato é que os elementos característicos, e que dariam maior valor ao futebol praticado no Brasil, podem ser percebidos com maior facilidade nas jogadas individuais de seus craques.

DaMatta (1982) também aborda este assunto dizendo que enquanto na Inglaterra e nos Estados Unidos o futebol tem a função de unificar e trazer a noção de coletividade em nações que são marcadas pelo individualismo, introduzindo conceitos como o fair play e a camaradagem, no Brasil ele é vivido como um jogo, e isso o torna uma fonte de individualismo, sendo distinguido da prática europeia justamente pela improvisação e individualidade. É dentro de um time de futebol que um membro dessa massa anônima e desconhecida pode tornar-se uma estrela e assim ganhar o centro das atenções como uma personalidade singular, insubstituível e capaz de despertar as atenções do público.

Voltando ao texto de Freyre, ele ainda faz referência a outro elemento típico da cultura africana que influenciou não só a sociedade brasileira, mas também seu futebol: a capoeiragem. Este costume, segundo ele, fez com que o futebol

\footnotetext{
${ }^{4}$ MARQUES. O futebol em Nelson Rodrigues, p. 54.
} 
"anguloso" dos ingleses, ou dos europeus em geral, tenha se tornado mais "arredondado" aos pés dos brasileiros. 0 autor releva, assim, a intensa mescla cultural, resultado de influências advindas de outras culturas - não só europeias, mas também ameríndias e africanas - encontradas na sociedade brasileira. A respeito disto, DaMatta (1994) também destaca a valorização que o futebol recebeu no Brasil por se tratar, assim como a capoeira, de um esporte praticado principalmente com a parte inferior do corpo: pés, pernas, quadris e cintura. Tais partes da anatomia humana seriam alvo de simbolismos e apreciação, e justamente através da atuação individual dos jogadores é que elas ficariam mais aparentes. Além disso, por ser jogado com os pés, o futebol torna-se menos previsível, o que agregaria a ele ideias de sorte, destino, predestinação, remetendo imediatamente a noções de religião e transcendência, esferas às quais os brasileiros estão profundamente ligados.

Mais tarde, Freyre dará mais uma contribuição importante acerca de sua visão sobre o futebol brasileiro e suas influências: trata-se do prefácio escrito para a primeira edição do livro $O$ negro no futebol brasileiro, de Mário Filho, publicado em 1947. Neste prefácio, que leva o mesmo título do livro no qual está inserido, Freyre (2003) diz que atividades típicas dos escravos africanos no Brasil, como a capoeira e o samba, estão nitidamente presentes na sociedade brasileira e, consequentemente, em seu futebol. Ainda segundo ele, o futebol, assim como outras oportunidades para feitos heroicos, como o serviço militar, acumula as energias psíquicas e os impulsos irracionais do homem brasileiro, que busca a sublimação.

O jornalista João Máximo (1999), assim como Freyre, compartilha a ideia do futebol brasileiro como futebol-arte, dizendo que existem diversos fatores que justificam este título, como a quantidade incomparável de títulos mundiais ganhos pela Seleção Brasileira, o número de craques brasileiros que atuaram no país e no exterior, a presença constante do Brasil em Copas do Mundo e o respeito e admiração pelo qual nosso futebol é reconhecido. 0 autor alega que mesmo o mercado milionário e global em que o esporte se transformou não seria o mesmo sem a influência do futebol brasileiro.

José Miguel Wisnik (2008) também faz uma análise da realidade brasileira baseando-se na obra de Machado de Assis, dizendo que nossa sociedade poderia 
ter traços de profundo descompromisso e imaturidade ou poderia ser a mais adiantada ou mais infantil das civilizações, ou seja, ela estaria compreendida "entre o Brasil remédio universal e o Brasil veneno de si mesmo". ${ }^{5} \mathrm{O}$ autor fala sobre este assunto para, finalmente, chegar à conclusão de que o futebol no século XX exemplificaria perfeitamente esta síndrome brasileira, como ele mesmo a classifica, que oscila entre uma ambição de máxima grandeza e uma impotência infantil. Ainda segundo ele, o futebol ofereceu à sociedade uma forma de balancear a busca por uma civilização avançada, combinada às gratificações infantis obtidas, por tratar-se de uma atividade que se aproxima do lúdico.

Para Wisnik, embora o futebol brasileiro possa ser comparado à arte, ele se diferencia dela à medida que não pode esconder suas imperfeições, ou seja, o rascunho não pode ser separado da obra prima; no mesmo lugar onde acontecem belas jogadas e passes desconcertantes, podem acontecer também diversos erros. Ao mesmo tempo, o autor atenta para a beleza do jogo em contraposição à "violência" da prática, ou seja, o futebol-arte contraposto ao futebol-rivalidade. Isto daria ao esporte um ar mais cético, deixando de ser comparado somente à arte, e sendo analisado de forma equilibrada e crítica. Por fim, Wisnik afirma que não tem a intenção de reconhecer as firulas e jogadas do futebol brasileiro como uma indicação de que ele se aproximaria da arte, mas sim observá-los de forma a entender como a cultura do Brasil penetrou neste esporte.

Em seu livro Pátria, chuteiras e propaganda: o brasileiro na publicidade da Copa do Mundo, Édison Gastaldo (2002) também se refere à obra de Freyre como uma forma de integração das diferenças, constituindo assim a identidade nacional. A interpretação freyreana foi tão incorporada na cultura brasileira que os desdobramentos de suas ideias se encontram entre os principais elementos que enfatizam a afirmação da nacionalidade nas publicidades referentes à Copa do Mundo. Gastaldo nos lembra de que a teoria proposta por Freyre ficou conhecida pelo "mito das três raças", que considerava a formação do povo brasileiro como um conjunto de influências culturais dos portugueses (brancos), dos africanos (negros) e dos índios autóctones. Tal teoria teria sido apropriada pelo Estado Novo

\footnotetext{
${ }^{5}$ WISNIK. Veneno remédio: o futebol e o Brasil, p. 170.
} 
de Vargas, sendo considerada por muito tempo como a interpretação oficial da cultura brasileira. Desta forma, o "ser brasileiro" seria o resultado de uma mistura de raças, sendo essencialmente tolerante já que é produto da integração das diferenças, característica que está refletida em manifestações como a religiosidade, o carnaval e o futebol. Ainda segundo Gastaldo, o discurso ideológico formado sobre o "ser brasileiro" teria sido apropriado pela publicidade, podendo ser encontrados diversos exemplos de peças publicitárias que utilizam a mistura racial e a integração de diferentes nacionalidades como tema.

Por fim, outra obra importante para se compreender a questão da habilidade do jogador brasileiro é a de Arlei Damo (2007) e as considerações acerca do dom para a prática do futebol. Para o autor, a palavra "dom" apresentase a partir de duas acepções distintas: como talento ou como dádiva. No primeiro caso, o "dom" representaria uma predisposição para a alta performance, como algo inato e imanente ao sujeito e passível de aperfeiçoamento. No segundo caso, o "dom" representaria uma predisposição para o sucesso a partir de algo que é herdado naturalmente, como uma dádiva divina. Em alguns juízos realizados pelos meios de comunicação, notadamente as emissoras de TV, os jogadores brasileiros seriam naturalmente dotados de habilidade, arte e magia, algo natural e reacendido especialmente em épocas de Copas do Mundo (Marques; Marcondes, 2015; 2016).

A visão do futebol-arte, aqui retratada, parece valorizar o futebol justamente pelo que ele não tem de objetividade. São principalmente os lances e jogadas que não possuem finalidade nenhuma além da plasticidade do movimento que encantam as torcidas e caracterizam o futebol brasileiro da forma como ele costuma ser lembrado. Pouco importa se o time ganhará com um gol de diferença no placar final ou mais; o que é relevante nas partidas, segundo os partidários do futebol-arte, são os dribles, a ginga, a malandragem desempenhada pelos jogadores. E tais características ficaram tão marcadas no imaginário brasileiro que, muitas vezes, se sobrepõem ao senso crítico, fazendo com que haja certo consenso a respeito de que o futebol brasileiro, dito futebol-arte, ainda é o grande símbolo da identidade nacional do país. Por essa visão, não bastaria ao futebol brasileiro apenas vencer, mas vencer jogando bonito. 


\section{O DISCURSO DISFÓRICO SOBRE O FUTEBOL BRASILEIRO}

Como visto até aqui, o futebol popularizou-se no Brasil ao ponto de tornar-se característico do país e parte fundamental da identidade nacional da população. Além de receber novas influências advindas da heterogeneidade presente na sociedade brasileira, especialmente da parcela afrodescendente, ele foi comparado a uma arte, graças ao talento dos jogadores e à forma como eles praticavam este esporte. Tamanho foi o impacto do futebol na vida dos brasileiros que a paixão causada aos poucos por este esporte foi utilizada até mesmo por outras esferas sociais, como a política, para estimular a unidade e o patriotismo da população. No entanto, atualmente, esta visão idílica sobre o futebol-arte tem sido desmistificada pelo discurso formado por alguns autores, que consideram o dito talento nato do brasileiro para a prática do futebol como algo pontual, e não como uma característica constante, como tem sido propagado ao longo dos anos.

No artigo "A produção das diferenças na produção dos 'estilos de jogo' no futebol: a propósito de um texto fundador", a antropóloga Simoni Lahud Guedes (2014), como o próprio título já indica, nomeia os textos de Freyre como "fundadores" da noção de que se praticaria no Brasil o futebol-arte. Segundo Guedes, no momento em que tais textos são escritos, dava-se início à ideia de que a seleção brasileira de futebol representaria em seu estilo e sua composição a própria sociedade do país. "Por intermédio da seleção brasileira de futebol ou, simplesmente, do Brasil no campo de futebol, têm sido discutidos os problemas e as potencialidades do país, bem como as qualidades e defeitos do 'povo brasileiro"”. 6

A autora ainda estabelece uma relação entre o dito "estilo de jogo" com o "estilo de vida" daqueles que o acompanham, dizendo que o desempenho de cada time é interpretado de acordo com a forma como os próprios torcedores e seus hábitos e costumes são representados. Aproximando-se do texto de Freyre (1938), Guedes (2014) analisa o estilo idealizado pelo autor como "estilo mulato", caracterizado pelos dribles e gracejos descritos por ele. No entanto, a autora contribui para a questão apontando o fato de que é impossível que qualquer estilo

\footnotetext{
${ }^{6}$ GUEDES. A produção das diferenças na produção dos 'estilos de jogo' no futebol: a propósito de um texto fundador, p. 156.
} 
de jogo esteja presente em todo o desempenho dos atletas pertencentes a um time ou seleção. Quando tal estilo é apresentado, mesmo que em raros momentos, o foco sobre eles os amplia, de forma a eternizá-los, seja por narrativas, fotos ou vídeos, tornando tal recorte significativo o bastante para confirmar o que se é dito sobre a maneira como um grupo de jogadores pratica o futebol. "O 'estilo de jogo' funda-se, portanto, tanto sobre a memória quanto sobre o silêncio, tanto sobre o que se diz quanto sobre aquilo que deve ser esquecido". 7 A conclusão é que expressões como futebol "à brasileira”, "futebol mulato", ou ainda o futebol-arte de Freyre não se tratam de descrições de algo ocorrido, mas sim de recortes de momentos pontuais do desempenho dos jogadores brasileiros, os quais são celebrados para simbolizar algo que não ocorre com a frequência desejada:

No caso do futebol brasileiro, o que fazemos quando separamos e destacamos estes momentos, na verdade absolutamente raros, de "dribles" ou "pedaladas", é reafirmar e reificar a forma como desejamos nos ver e, com isso, produzimos, reproduzimos e, eventualmente, reformamos e reinventamos essa forma em um processo contínuo. ${ }^{8}$

Guedes (2014) ainda aponta para o fato de que essa permissividade do futebol em relação a novos estilos e jogadas não vem de sua classificação como esporte coletivo, visto que outros esportes com a mesma característica, como o vôlei, não possuem tal maleabilidade. Segundo a autora, o caso do futebol diferencia-se justamente por haver um menor controle a respeito dos desempenhos de cada time, ou seja, não há tantos movimentos físicos que devam ser respeitados à risca como em outras modalidades, como o atletismo ou mesmo o vôlei, o que abre espaço para a produção de diferenças e interpretação de desempenho. Guedes acredita que é justamente essa característica de permitir a produção de diferenças que fez com que o futebol fosse tão difundido pelo mundo todo, mesmo em nações que são distantes culturalmente.

Assim como Guedes, Maranhão faz uma ressalva sobre a visão idílica de Gilberto Freyre a respeito do futebol brasileiro, dizendo que não se pode afirmar que o futebol como símbolo da democracia racial brasileira não tenha sido uma invenção. "O

\footnotetext{
${ }^{7}$ GUEDES. A produção das diferenças na produção dos 'estilos de jogo' no futebol: a propósito de um texto fundador, p. 159.

${ }^{8}$ GUEDES. A produção das diferenças na produção dos 'estilos de jogo' no futebol: a propósito de um texto fundador, p. 161.
} 
que se pretende deixar claro, contudo, é que depois de 'inventado' e o mais importante, depois de assimilado e aceite pela sociedade, é inegável o papel do futebol na construção de uma subjectividade colectiva em relação à nação brasileira". 9

Sobre as classificações criadas por Freyre (futebol "apolíneo" e "dionisíaco"), Maranhão pontua que o escritor não reserva somente esta divisão ao futebol, mas à população, considerando que a racionalidade e a lógica são atributos essencialmente europeus, não cabendo nos elogios que ele tece à naturalidade do povo africano e seus descendentes, que seriam nascidos para a dança, música, luta e para o futebol. E mais do que isso, Freyre dizia ser possível que o intelecto europeu coexistisse com o primitivismo afro-brasileiro no mulato, que seria segundo ele o "verdadeiro brasileiro".

Ronaldo Helal, sociólogo e pesquisador da relação do esporte com a comunicação, também costuma relativizar a visão das obras de Freyre sobre o futebol brasileiro e a dicotomia entre os estilos de jogo. Em texto escrito em 2012 para o jornal $O$ Globo, Helal afirma que os adjetivos utilizados por Gilberto Freyre para descrever o futebol no Brasil são relembrados principalmente quando quem se encontra em campo é a Seleção Brasileira de futebol, como se a imprensa buscasse através da ideia do futebol-arte uma forma de assegurar a brasilidade no estilo de praticar este esporte. Além disso, para Helal, a ideia de Freyre a respeito do malandro no futebol brasileiro, do sucesso sem esforço, faz com que seja quase depreciativo se referir a um jogador dizendo que ele é esforçado. Segundo o autor, exemplo claro desta valorização do malandro é o caso da seleção que disputou a Copa do Mundo de 1970: "Ela é idealizada como uma equipe que não precisava treinar. No entanto, temos evidências de que aquela seleção se utilizou de métodos de preparação física dos mais modernos da época". 10

Helal ainda comenta sobre casos de jogadores considerados ídolos do futebol brasileiro e que não se enquadram no perfil do malandro, como Pelé e Zico, que construíram suas carreiras a partir da dedicação aos treinos e ao cuidado com o corpo. Isso mostraria uma falha no pensamento de Freyre, de separar o futebol

\footnotetext{
9 MARANHÃO. "Apolíneos e dionisíacos" - o papel do futebol no pensamento de Gilberto Freyre a respeito do "povo brasileiro, p. 442.

${ }^{10}$ HELAL. Heróis Malandros?, 2012.
} 
apolíneo do dionisíaco, já que alguns de nossos maiores ídolos seriam reconhecidos por uma conduta que se aproxima mais da apolínea.

Helal e Gordon (2002) afirmam ainda que o processo de popularização do futebol no Brasil foi permeado por um trabalho executado por agentes do universo político e esportivo para que se criasse um espaço naturalizado para o esporte, ou seja, a intenção era que se promovesse uma associação simbólica do futebol com a realidade presente na sociedade brasileira, no caso, o Estado-Nação e o povo, como descrito anteriormente. Ainda segundo os autores, entre as décadas de 1930 e 1950, a popularização deste esporte foi alavancada não só por sua profissionalização, mas principalmente por setores da intelectualidade e pela imprensa, que fizeram do futebol um espetáculo direcionado às massas, constituinte da cultura popular. Ainda segundo estes autores, foram tais intelectuais e agentes da imprensa os responsáveis por iniciar a difusão da ideia de que o Brasil possuía um estilo próprio de jogar futebol, como se quando praticado pelos brasileiros, este esporte ganhasse traços de seu caráter, resultado, por sua vez, da mescla entre as culturas europeias e africanas (brancos e negros). "Daí a ideia de que o futebol brasileiro se manifesta em campo como uma espécie de dança, e que expressa características tais como malícia, arte, musicalidade, ginga e espontaneidade".11

É interessante perceber que Helal e Gordon tratam o futebol-arte como uma ideia, e não um fato, criado e difundido por intelectuais e profissionais da imprensa. Neste caso, nota-se um posicionamento que coloca em dúvida se o futebol praticado no Brasil na realidade é o mesmo daquele divulgado pelos veículos de comunicação. Os próprios autores dizem ser esta visão do futebol brasileiro, definidor de identidade, como uma "metáfora poderosa, pois transcende os limites do campo acadêmico e intelectual (onde foi gerada), para se tornar uma ideologia amplamente difundida e absorvida pelo senso comum". ${ }^{12}$ Eles ainda apontam as Copas do Mundo de 1950, 1958, 1962 e 1970 como eventos em que se pôde enxergar claramente a proporção que tal metáfora havia tomado, com a presença de jogadores negros e mestiços e as vitórias alcançadas após 1950 como prova do futebol dito artístico.

\footnotetext{
${ }^{11}$ HELAL; GORDON. A crise no futebol brasileiro: perspectivas para o século XXI, p. 43.

${ }^{12}$ HELAL; GORDON. A crise no futebol brasileiro: perspectivas para o século XXI, p. 44.
} 
Sob a ótica desta formação discursiva, o enquadramento dado à Seleção Brasileira na Copa do Mundo de 1970 colaborou intensamente para o adensamento da identidade nacional brasileira atrelada à noção do futebol habilidoso, pleno de ginga, dribles, improvisação e malandragem. Aspectos táticos e físicos que contribuíram para o sucesso do Brasil naquela competição foram paulatinamente esquecidos, em favor da suposta habilidade incontestável dos jogadores nacionais, perpetuando-se assim a ideia do futebol genial e criativo dos brasileiros. E mais uma vez, a dita "metáfora" do futebol-arte foi tão intensificada pela imprensa em 1970, que acabou reverberando na seleção escalada para a Copa de 1982. Mesmo tendo terminado a competição em quinto lugar, este grupo de jogadores foi considerado exemplo das características pelas quais o futebol brasileiro é reconhecido, como se fosse uma extensão da seleção que disputou o evento doze anos antes (Santoro; Soares, 2009).

Franco Júnior (2013) vai além da ideia de Soares, Helal e Santoro (2004) em relação ao futebol-arte no Brasil, apresentando-o como uma falácia, quando se refere ao que tem sido visto do esporte na atualidade:

Parte essencial do clichê "Brasil, país do futebol" é a crença de que aqui se joga com mais habilidade, com mais qualidade. A rigor, porém, o nível de nossas competições é mediano, quando não baixo. 0 enquadramento institucional impede que a potencialidade esportiva se torne realidade. ${ }^{13}$

Soares, Helal e Santoro (2004) dizem, ainda, que a construção da ideia de uma forma característica de se praticar o futebol no Brasil funcionou como uma forma dos habitantes do país se afirmarem culturalmente perante o resto do mundo. Assim, a produção de narrativas sobre o futebol assumia o discurso da "essência" do ser brasileiro. Os autores apontam para o fato de que, tendo sido construída em grande parte por narrativas jornalísticas, a memória do futebol brasileiro está repleta de parcialidades, seguindo a tendência na qual está fundamentada, de que este esporte no Brasil remete mais ao artístico do que ao técnico. Como exemplo, eles também citam a Copa do Mundo de 1970, afirmando que a memória da seleção que disputou este evento foi embasada apenas nos

\footnotetext{
${ }^{13}$ FRANCO JÚNIOR. Brasil, país do futebol, p. 50.
} 
aspectos que diziam respeito ao talento dos jogadores, em detrimento da preparação técnica pela qual a equipe passou durante todo o período de treinamento e de preparação, iniciado ainda no Brasil - antes da viagem ao México.

\section{ALGUMAS CONSIDERAÇ̃̃ES FINAIS}

Neste artigo, trabalhamos com a ideia de que há dois discursos concomitantes a respeito do futebol brasileiro: um que tende a caracterizá-lo como arte ou algo próximo da arte, e outro que procura desmistificar essa caracterização. Por meio dos autores e da bibliografia aqui relacionada, pôde-se entender como ambos os discursos foram formados e difundidos de diferentes maneiras: o futebol-arte, surgido no meio acadêmico e intelectual, teve uma divulgação massiva e uma reatualização por parte dos meios de comunicação, tornando-se um elemento unificador da sociedade brasileira. Já o futebol compreendido sob uma nova ótica da academia acabou ficando mais circunscrito à comunidade universitária e ao universo da pesquisa no campo das humanidades e das ciências da comunicação, posicionando-se de forma destoante da visão deste esporte à qual a população do país está acostumada.

De fato, o futebol valorizado pelos brasileiros é justamente aquele praticado de forma poética, como defendia Pasolini, talvez porque seja entendido como o "verdadeiro" futebol do Brasil, aquele que é mais reconhecido pelos dribles e firulas do que pelos passes e jogadas coletivas. Elementos da cultura que identificam o estilo brasileiro de se praticar esse esporte (como a malícia, a valorização de certas partes do corpo e a transgressão à autoridade) acabam por ser mais associados às jogadas individuais do que aos arranjos coletivos ou físicos.

Essa identificação causada pelo formato singular do esporte praticado no país, assim como na política, tem sido muito visada também pelo mercado como um apelo publicitário eficaz na divulgação de suas marcas, produtos e serviços. Entendendo as emissoras de televisão como empresas do mercado de comunicação, o futebol e, especialmente, eventos como a Copa do Mundo, são oportunidades de garantir a identificação do público, principalmente se a ideia de "melhores do 
mundo" e o sentimento de patriotismo estiverem atrelados ao conteúdo exibido nas produções, que chamam os telespectadores a acompanhar o campeonato.

De todo modo, o discurso recente da academia a respeito do futebol brasileiro vê o futebol-arte de Gilberto Freyre mais como uma exceção do que como regra, como discutido nestas páginas. Não se pode negar que alguns jogadores brasileiros atuais e recentes, como Neymar, Ronaldo, Ronaldinho Gaúcho, Robinho e muitos outros, possuam uma forma característica de praticar futebol; mas também não se pode dizer que tal estilo pertença unicamente a eles. Hoje, outros jogadores, de diversas nacionalidades, possuem grande habilidade com a bola, utilizando-se de "firulas" e transgressões para "embelezar" o jogo. Também não se pode deixar de lado o fato de que algumas seleções brasileiras demonstraram extrema destreza na prática do chamado futebol-arte em vários mundiais. No entanto, embora esta seja a visão difundida preferencialmente pela mídia, a partir do momento em que a maior parte das Copas do Mundo foi marcada por uma atuação regular dos jogadores brasileiros, e não tão artística, relativiza-se assim a visão idílica de Gilberto Freyre.

\section{REFERÊNCIAS}

DAMATTA, Roberto. Antropologia do óbvio. Revista USP. São Paulo, n. 22, p. 10-17, jun-jul-ago, 1994.

DAMATTA, Roberto. Esporte na Sociedade: Um Ensaio sobre o Futebol Brasileiro. In: DAMATTA, Roberto. Universo do Futebol: esporte e sociedade brasileira. Rio de Janeiro: Pinakotheke, 1982.

DAMO, Arlei. Do dom à profissão: a formação de futebolistas no Brasil e na França. São Paulo: HUCITEC, 2007.

FRANCO JÚNIOR, Hilário. Brasil, país do futebol?. Revista USP, São Paulo, n. 99, p. 45-56, set.-nov. 2013. 
FRANZINI, Fábio. As raízes do país do futebol: estudo sobre a relação entre o futebol e a nacionalidade brasileira (1919 - 1950). 2000. 153 f. Dissertação (Mestrado em História Social) - Faculdade de Filosofia, Letras e Ciências Humanas, Universidade de São Paulo, São Paulo, 2000.

FREYRE, Gilberto. Foot-ball mulato. Diário de Pernambuco, Recife, 17 jun. 1938.

GASTALDO, Édison. A Pátria na "imprensa de chuteiras": futebol, mídia e identidades brasileiras. In: ANPOCS, XXVII, 2003, Caxambu. Encontro Anual da ANPOCS - Associação Nacional em Pós-Graduação e Pesquisa em Ciências Sociais. Congresso, ANPOCS.

GASTALDO, Édison. Pátria, chuteiras e propaganda: o brasileiro na publicidade da Copa do Mundo. São Paulo: Annablume; São Leopoldo: Ed. Unisinos, 2002.

GUEDES, Simoni Lahud. A produção das diferenças na produção dos 'estilos de jogo' no futebol: a propósito de um texto fundador. In BUARQUE DE HOLLANDA, B. B.; BURLAMAQUI, L. G. (Orgs.). Desvendando o jogo - nova luz sobre o futebol. Niterói: Editora da UFF - FAPERJ, 2014.

HELAL, Ronaldo. Heróis Malandros?. O Globo, Rio de Janeiro, 02 nov. 2012.

HELAL, Ronaldo; GORDON, Cesar. A crise no futebol brasileiro: perspectivas para o século XXI. ECO-PÓS, Rio de Janeiro, v. 5, n. 1, p. 37-55, 2002.

HOBSBAWN, Eric; RANGER, Terence (Orgs.). A invenção das tradições. Rio de Janeiro: Paz e Terra, 1997.

MARANHÃO, Tiago. "Apolíneos e dionisíacos" - o papel do futebol no pensamento de Gilberto Freyre a respeito do "povo brasileiro". Análise Social. Lisboa, v. 41, n. 179, p. 435-450, 2006.

MARQUES, José Carlos. O futebol em Nelson Rodrigues. São Paulo: Educ, 2012.

MARQUES, José Carlos; MARCONDES, Nathaly B. A vinheta oficial da FIFA para a Copa do Mundo de 2014 e o futebol-arte de Gilberto Freyre: aproximações estéticas e apropriação publicitária. Eptic (UFS), v. 18, p. 133-149, 2016.

MARQUES, José Carlos; MARCONDES, Nathaly B. Um por todos, todos por um: a individualidade e o "futebol arte" brasileiro analisados em três momentos da Copa do Mundo de 2014. In: ARAÚJO, Allyson Carvalho (Org.). Copa do Mundo 2014: debates sobre mídia e cultura. Natal: EDUFRN, 2015, v. 1, p. 115-144.

MÁXIMO, João. Memórias do futebol brasileiro. Estudos Avançados. São Paulo, v. 13, n. 37, p. 179-188, 1999.

PASOLINI, Pier Paolo. O gol fatal. Folha de S. Paulo. São Paulo: 06 mar. 2005. Caderno Mais!, p. 4.

ROSENFELD, Anatol. Negro, Macumba e Futebol. São Paulo: Perspectiva: Editora da Universidade de São Paulo; Campinas: Editora da Universidade Estadual de Campinas, 1993.

SANTORO, Marco A.; SOARES, Antônio J. G. A memória da Copa de 1970: esquecimentos e lembranças do futebol na construção da identidade nacional. Campinas: Autores associados, 2009. 
SOARES, Antônio J.; HELAL, Ronaldo; SANTORO, Marco A. Futebol, imprensa e memória. Revista Fronteiras - estudos midiáticos. São Leopoldo, v. 6, n. 1, p. 61-78, jan/jun 2004.

SOARES, Antônio J.; LOVISOLO, Hugo R. Futebol: a construção histórica do estilo nacional. Revista Brasileira de Ciências do Esporte, Campinas, v. 25, n. 1, p. 129-143, set. 2003.

VOGEL, Arno. O momento feliz - reflexões sobre o futebol e o ethos nacional. In: DAMATTA, Roberto et al. Universo do Futebol: esporte e sociedade brasileira. Rio de Janeiro: Pinakotheke, 1982.

WISNIK, José Miguel. Veneno remédio: o futebol e o Brasil. São Paulo: Companhia das Letras, 2008. 